\title{
From Neuroendocrinology to Neuroimmunomodulation - A Tribute to Prof. Dr. Samuel McCann
}

\author{
Stefan R. Bornstein \\ Department of Medicine, University of Dresden, Carl Gustav Carus, Dresden, Gemany
}

\section{Key Words}

Samuel McCann $\cdot$ Neuroendocrinology $\cdot$ Releasing hormone

\begin{abstract}
One of the leading experts in the field of Neuroendocrinology and Neuroimmunmodulation, Samuel Mac Donald McCann, known by all his friends as 'Don', passed away in 2007. This article pays tribute to his outstanding scientific contribution and a glimpse on his fascinating personality. A member of the National Academy of Sciences of the United States and pioneer in the field of neuroendocrine regulation, he identified numerous hormones and peptides and set the stage for basic concepts in physiology and clinical medicine.

Copyright $\odot 2007$ S. Karger AG, Basel
\end{abstract}

Prof. Dr. Samuel McCann passed away in 2007 in the city of Buenos Aires. With him the world has lost one of the greatest scientists in the field of neuroendocrinology.

At the Iberoamerican Congress on Neuroimmunomodulation in Madrid this year, I had the honor to give a lecture on his behalf that he could not present himself, since passing away a few weeks earlier. This lecture was entitled 'The history of neuroimmunomodulation'. Prof.
McCann recognized the immense significance of the cross talk of the nervous and endocrine system with the immune system. His broad vision and bright intellect acknowledged the fact that biological sciences cannot be reduced to genomic and proteomic profiles or a single cellular signaling pathway, but have to be seen as a whole in the context of physiology.

With the above vision in mind he cofounded the Journal of Neuroimmunomodulation, representing today a vivid and active group of scientists dedicated to further our knowledge on the interface of immunology and neurobiology and the translation of these findings to the clinic.

Prof. McCann sent me some of his slides, recognizing that he would not be able to come to Madrid. I realize that a talk appreciating the enormous achievements of 'Don' (this is how all his friends called him), is almost identical to a comprehensive history of neuroendocrinology and neuroimmunomodulation. This can only be a short appraisal of his unique character and personality.

In an unusually productive career spanning over 60 years, he worked in many places (including Bethesda, Dallas, Baton Rouge, Buenos Aires and many more) on all major areas of neuroendocrinology and neuroimmunomodulation, publishing more than 1,000 papers and books in the field. Needless to say that it would require a whole book to give tribute to all his achievement. Therefore, I selected only a few of his outstanding contributions

\section{KARGER}

Fax +4161306 1234 E-Mail karger@karger.ch www.karger.com (c) 2007 S. Karger AG, Basel

1021-7401/07/0144-0122\$23.50/0

Accessible online at:

www.karger.com/nim
Prof. Stefan R. Bornstein

Department of Medicine, University of Dresden

Carl Gustav Carus, DE-01307 Dresden (Germany)

Tel./Fax +49451 4585955

E-Mail stefan.bornstein@uniklinikum-dresden.de 
Fig. 1. Prof. McCann performed pioneering work with these factors. LHRL = Luteinizing hormone releasing factor; FSH-RH = follicle-stimulating hormonereleasing hormone; $\mathrm{CRH}=$ corticotropin releasing hormone; GNRH = gonadotropin-releasing hormone; $\alpha$-MSH $=\alpha$-melanocyte-stimulating hormone; LPS = lipopolysaccharide.
Fig. 2. Prof. McCann's research had a major impact on clinical medicine.
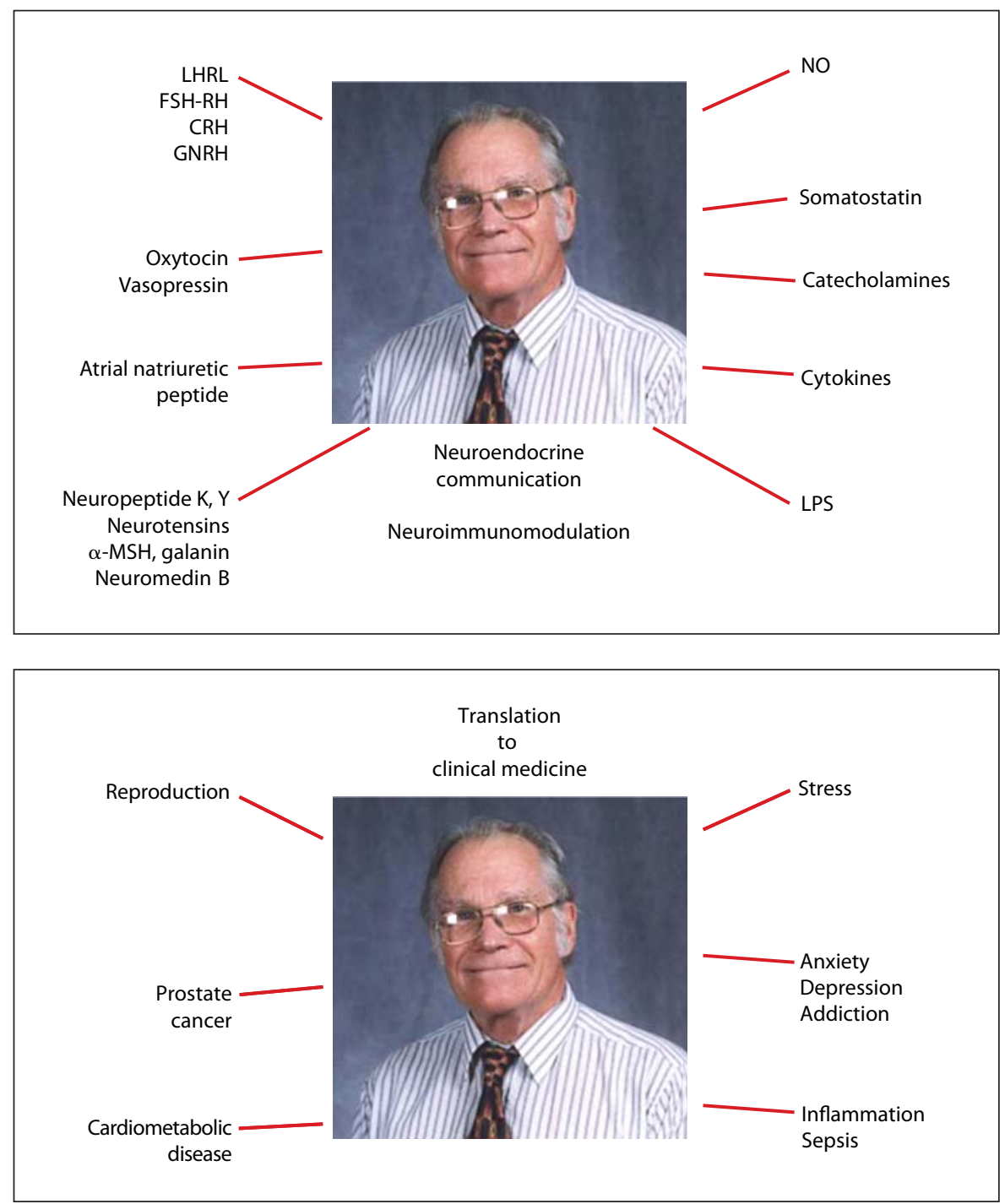

in neuroendocrinology. His work included: hypothalamic control of water intake [1], suppression of adrenal compensatory hypertrophy by hypothalamic lesions [2], the effect of hypothalamic lesions on the secretion of luteotrophin [3], physiological control of ovulation [4], a hypothalamic follicle stimulating hormone-releasing factor [5], the neuroendocrine regulation of hypophyseal luteinizing hormone secretion [6] and arginine vasopressin as a thyrotropin-releasing hormone [7] (fig. 1).

Furthermore, he was among the pioneers to unravel the cross talk of neuroendocrine cells with the immune system forming the basis of the field of neuroimmunomodulation [8-13].

Finally, he was among the first to recognize the neuroendocrine basis of the metabolic syndrome [14-19].
Until the very last days of his life he managed to stay updated with the latest developments in science.

A tribute to Professor McCann would, however, be incomplete without a record on the man as a mentor and inspiration to all of us. Therefore, I would like to provide a selection of some of the messages that were sent to me in preparation of my talk from all over the world that may represent the feelings and impressions of many of us.

\section{Andrew V. Schally, Nobel laureate,}

University of Miami

'I was profoundly saddened by the passing of Professor Samuel M. (Don) McCann. Don McCann was a great neuroendocrinologist and one of the pioneers in hypothalamic releasing hormones. His work in the 1950's and 
1960 's greatly contributed to the elucidation of the mechanisms through which hypothalamus controls the secretion of ACTH, luteinizing hormone and growth hormone from the anterior pituitary gland. Somatostatin was also discovered in Don's laboratory. His pioneer studies on the hypothalamus and physiology of LH release were recognized by the Endocrine Society award. His work made possible subsequent isolation and identification of several hypothalamic hormones. It was my pleasure and privilege to be his friend and we published some scientific papers together. It was also my honor to nominate Don for the membership in the National Academy of Sciences of the USA in recognition of his outstanding contributions to neuroendocrinology. In later years Don McCann established successful international collaboration with neuroendocrinologists in Argentina and Brazil. With the passing of Don McCann the world loses a great scientist and a pioneer in neuroendocrinology.'

Jose Antunes-Rodrigues, João César Bedran de Castro, Celso Rodrigues Franci, Janete A. Anselmo Franci,

Carmen Cabanelas Pazos de Moura,

Egberto Gaspar de Moura and Umeko Marubayashi,

Universidade de São Paulo

'O Prof. McCann será sempre lembrado como um dos pioneiros da Neuroendocrinologia contemporânea e um ser humano de inestimável valor. Sua sabedoria, cultura e visão humanística da ciência fizeram dele um modelo a ser seguido por todos nós. Realizou uma obra fundamental, dessas que marcam época, definem caminhos e servem de exemplo. A ele a nossa gratidão eterna.'

\section{Ma-Li Wong and Julio Licinio, University of Miami \\ 'We take our hats off for you Don! - Eulogy to Samuel M. McCann}

Brilliance, relentless and amazing are the words that are perfect to describe Don McCann; they also punctuated his last conscious moments on March 16th, 2007 when we got his final phone call.

Septic, cachetic and hypotensive, Don managed to gather the strengths to reach us in order to consult about his treatment choices at 3 a.m. local time in Buenos Aires. His strong voice and clear state of mind were startling. We were profoundly touched, as we knew that Don was

completeness about his work and his mission, which he conquered by his tireless lifetime determination.

A few hours later the world lost a great person and mind with his passing away at the University Hospital of Buenos Aires.'

\section{Claudio Mastronardi, University of Miami}

'I ended up spending five wonderful years in his lab, until I completed my $\mathrm{PhD}$ thesis under his supervision. He was an excellent and encouraging boss who was always ready to discuss research. His ideas were very clear and so was the way he approached them.

Inspired by the "in vivo veritas" models, he advised me to do in vivo experiments "to go to the jugular of the problem" and to do it in a simple way.

I could not help to consider him as my scientific father, and even more, in some circumstances ... just as my father.

I was ready to become a father but since I could not see a clear outcome in the future, I hesitated to the point of preventing my wife and I to have kids. I will always remember the deep sense of security and the intensity of the expression in his face when he suddenly told me: "All the women should have at least one child; otherwise they will not feel fulfilled in their life. Do not worry about the future, remember the words from the bible: "God will provide ...". Therefore Don McCann will live on in the eyes of my children.'

Finally, I would like to thank Dr. Valeria Rettori for taking care of her husband Prof. McCann. Valeria Rettori, a brilliant scientist herself, has spent a major part of her scientific career with Don McCann. Both published and worked together until the last moment. When Don was in a desperate situation in a community hospital in Baton Rouge, it was Valeria who took him to Buenos Aires to recover and regain the positive spirits of life. Without her the world would have lost a great mind many years earlier. Don McCann followed the definition of true wisdom, a man with an open mind who learned from everybody, a man who did not work just for himself but for his team and therefore for his legacy. sharing his goodbye message.

We prayed for the impossible, hoping that he could again miraculously defeat death, as he had done more than twice before with the help of Valeria Rettori. But, differently from previous times, he conveyed a sense of

References
1 Andersson B, McCann SM: Hypothalamic control of water intake. J Physiol 1955;129: $44 \mathrm{P}$

2 Fulford BD, McCann SM: Suppression of adrenal compensatory hypertrophy by hypothalamic lesions. Proc Soc Exp Biol Med 1955;90:78-80. 
3 McCann SM, Friedman HM: The effect of hypothalamic lesions on the secretion of luteotrophin. Endocrinology 1960;67:597608.

4 McCann SM: Physiological control of ovulation. Physiol Pharmacol Physicians 1963; 104:1-6.

5 Igarashi M, McCann SM: A hypothalamic follicle stimulating hormone-releasing factor. Endocrinology 1964;74:446-452.

6 McCann SM, Ramirez VD: The neuroendocrine regulation of hypophyseal luteinizing hormone secretion. Recent Prog Horm Res 1964;20:131-181.

7 Lumpkin MD, Samson WK, McCann SM: Arginine vasopressin as a thyrotropin-releasing hormone. Science 1987;235:10701073.

8 Mastronardi C, Whelan F, Yildiz OA, Hannestad J, Elashoff D, McCann SM, et al: Caspase 1 deficiency reduces inflammation-induced brain transcription. Proc Natl Acad Sci USA 2007;104:7205-7210.

9 Fernandez-Solari J, Prestifilippo JP, Bornstein SR, McCann SM, Rettori V: Participation of the endocannabinoid system in the effect of TNF- $\alpha$ on hypothalamic release of gonadotropin-releasing hormone. Ann NY Acad Sci 2006;1088:238-250.
10 McCann SM, De Laurentiis A, Rettori V: Chronology of advances in neuroendocrine immunomodulation. Ann NY Acad Sci 2006;1088:1-11.

11 Zacharowski K, Zacharowski PA, Koch A, Baban A, Tran N, Berkels R, et al: Toll-like receptor 4 plays a crucial role in the immuneadrenal response to systemic inflammatory response syndrome. Proc Natl Acad Sci USA 2006;103:6392-6397.

12 Mohn CE, Fernandez-Solari J, De Laurentiis A, Prestifilippo JP, de la Cal C, Funk R, et al: The rapid release of corticosterone from the adrenal induced by ACTH is mediated by nitric oxide acting by prostaglandin E2. Proc Natl Acad Sci USA 2005;102:6213-6218.

13 Bornstein SR, Zacharowski P, Schumann RR, Barthel A, Tran N, Papewalis C, et al: Impaired adrenal stress response in Toll-like receptor 2-deficient mice. Proc Natl Acad Sci USA 2004; 101:16695-16700.
14 Mastronardi CA, Srivastava V, Yu WH, Les DW, McCann SM: Lipopolysaccharide-induced leptin synthesis and release are differentially controlled by $\alpha$-melanocyte-stimulating hormone. Neuroimmunomodulation 2005; $12: 182-188$

15 Yildiz BO, Suchard MA, Wong ML, McCann SM, Licinio J: Alterations in the dynamics of circulating ghrelin, adiponectin, and leptin in human obesity. Proc Natl Acad Sci USA 2004;101:10434-10439.

16 Ehrhart-Bornstein M, Lamounier-Zepter V, Schraven A, Langenbach J, Willenberg HS, Barthel A, et al: Human adipocytes secrete mineralocorticoid-releasing factors. Proc Natl Acad Sci USA 2003;100:14211-14216.

17 Zouboulis CC, Seltmann H, Hiroi N, Chen W, Young M, Oeff M, et al: Corticotropinreleasing hormone: an autocrine hormone that promotes lipogenesis in human sebocytes. Proc Natl Acad Sci USA 2002;99:71487153.

18 Mastronardi CA, Yu WH, Srivastava VK, Dees WL, McCann SM: Lipopolysaccharideinduced leptin release is neurally controlled. Proc Natl Acad Sci USA 2001;98:1472014725.

19 McCann SM: The nitric oxide hypothesis of brain aging. Exp Gerontol 1997;32:431-440. 